\title{
Sensitivities of mRNA expression levels of Kiss1 and its receptor, Kiss $1 r$, to nutritional status are changed during the developmental period in female rats
}

\author{
Takeshi Iwasa, Toshiya Matsuzaki, Masahiro Murakami, Riyo Kinouchi, Ganbat Gereltsetseg, \\ Shinobu Fujisawa, Akira Kuwahara, Toshiyuki Yasui and Minoru Irahara \\ Department of Obstetrics and Gynecology, Institute of Health Biosciences, The University of Tokushima Graduate School, 3-18-15 Kuramoto-Cho, \\ Tokushima 770-8503, Japan \\ (Correspondence should be addressed to T Iwasa; Email: takeshi1@clin.med.tokushima-u.ac.jp)
}

\begin{abstract}
Decreased activity of kisspeptin, the product of the hypothalamic Kiss 1 gene, is the major cause of the suppression of reproductive function in subnutritional conditions. The sensitivities of the endocrine and the hypothalamic neuronal systems to nutritional status develop during the neonatal period. We examined the developmental changes in the sensitivity of hypothalamic mRNA expression of Kiss 1 and its receptor, Kiss1r, to nutritional status in female rats. Kiss 1 mRNA expression was reduced by $24 \mathrm{~h}$ food deprivation (24 h FD) at postnatal day 25, but not at postnatal day 5 or 15 . Kiss $1 \mathrm{r}$ mRNA expression was reduced by the 12 or $24 \mathrm{~h}$ FD at postnatal days 5 and 25, but not at postnatal day 15. Kiss $1 r$ mRNA level was found to be correlated with the plasma leptin level, and the administration of leptin, which increased
\end{abstract}

the serum leptin concentration above the physiological range, restored the acute FD-induced suppression of Kiss $1 r$ mRNA expression. These data suggest that the hypothalamic Kiss 1 and Kiss $1 r$ mRNA expression is differentially affected by the nutritional condition at different age points. It is speculated that the sensitivity of Kiss 1 mRNA, which is expressed in kisspeptin neuron, to nutritional status develops during the neonatal period. On the other hand, it seems that the sensitivity of Kiss $1 r$ mRNA, which is expressed in GnRH neuron, to nutritional status has been already established during the early neonatal period. These data also show that hypoleptinemia plays a role in the reduction of hypothalamic Kiss $1 r$ mRNA expression under subnutritional conditions.

Journal of Endocrinology (2010) 207, 195-202

\section{Introduction}

Reproductive function is highly sensitive to metabolic and nutritional status. Both pulsatile secretion of $\mathrm{LH}$ and the $\mathrm{LH}$ surge are inhibited by short-term food deprivation (FD) in ovariectomized estradiol $\left(\mathrm{E}_{2}\right)$ and/or progesterone-primed female rodents (McClure \& Saunders 1985, Cagampang et al. 1991, Wade \& Schneider 1992, Kohsaka et al. 2001). Similarly, the estrous cycle is disrupted (Knuth \& Friesen 1983) and sexual maturation is delayed by chronic food restriction in gonadal intact female rats (Castellano et al. 2005). Recently, kisspeptin, the product of the Kiss 1 gene, and its receptor, Kiss1r, a product of the $G$ protein-coupled receptor 54 (GPR54) gene, have emerged as essential gatekeepers of reproduction. GnRH and the gonadotrophin release are stimulated and sexual maturation is accelerated by the administration of kisspeptin in several species (Gottsch et al. 2004, Irwig et al. 2004, Navarro et al. 2004, 2005, Messager et al. 2005, Shahab et al. 2005, Roseweir \& Millar 2009). On the other hand, hypogonadotropic hypogonadism and delayed sexual maturation are induced by loss-of-function point mutations and deletion of GPR 54 in humans and mice (de Roux et al. 2003, Seminara et al. 2003). Experimental evidence suggests that a decrease in the activity of kisspeptin is the main cause of the inhibition of reproductive function observed in subnutritional conditions. Hypothalamic Kiss $1 \mathrm{mRNA}$ expression is reduced in acute food-deprived female rodents (Castellano et al. 2005, Luque et al. 2007, Brown et al. 2008) and streptozotocin-induced diabetic male rats (Castellano et al. 2006), and hypogonadotropic hypogonadism can be restored in these animals by the administration of kisspeptin (Castellano et al. 2005, 2006, Luque et al. 2007). On the other hand, the effects of FD on Kiss1r are disputed. Although hypothalamic Kiss $1 r$ mRNA expression is increased by $72 \mathrm{~h}$ FD in prepubertal rats (Castellano et al. 2005), its expression levels are reduced by 12-48 h FD in adult mice (Luque et al. 2007).

It is suggested that leptin transmits signals related to energy balance to kisspeptin neurons through its receptor, Ob-R (Smith et al. 2006, Castellano et al. 2009, Roa et al. 2010) and acts as a positive regulator of the hypothalamic kisspeptin system. Kiss 1 mRNA expression is lower in leptin-deficient 
$\mathrm{ob} / \mathrm{ob}$ mice than in wild-type mice (Smith et al. 2006, Castellano et al. 2009, Roa et al. 2010), and the reduced Kiss 1 mRNA expression seen in streptozotocin-induced diabetic male rats can be normalized by central leptin infusion (Castellano et al. 2006, 2009, Roa et al. 2010). In addition, the mRNA expression levels of Kiss 1 and Kiss $1 r$ in primary cultures of human fetal GnRH-secreting neuroblasts are increased by the addition of leptin (Morelli et al. 2008).

It has been reported that the neuronal pathways in the hypothalamus develop rapidly during the neonatal period (Bouret et al. 2004, Bouret 2010). The neuronal projections from the arcuate nucleus (ARC) to the periventricular nucleus (PeN) develop from postnatal day 8 , and the mature patterns of innervation are achieved by postnatal day 16 (Bouret et al. 2004). Similarly, neuronal projection of kisspeptin also develops during the neonatal period (Clarkson \& Herbison 2006). In addition, experimental data have suggested that the sensitivity of some endocrine and hypothalamic neuronal systems to metabolic and nutritional status develops simultaneously with their neuronal projection during the neonatal period. For example, the sensitivity of hypothalamic orexigenic and anorexigenic factors to leptin develops during the neonatal period, and the anorectic effects of leptin on appetite and feeding behaviors are acquired during the same period in mice and rats (Mistry et al. 1999, Carlo et al. 2007). Similarly, the adrenal response to FD is established during the neonatal period in mice (Ahima et al. 1998). It has also been reported that an abnormally high or low nutritional status during the fetal or neonatal period permanently affects hypothalamic function and induces metabolic diseases in later life in humans and experimental animals (Barker et al. 1993, Proulx et al. 2002, Yura et al. 2005, Bouret et al. 2008, Delahaye et al. 2008, Remmers et al. 2008, Breton et al. 2009, Kirk et al. 2009). Although the effects of undernutrition on kisspeptin action have been investigated in mice and rats at various reproductive ages, the developmental changes that occur in the sensitivity of the kisspeptin system to nutritional status have not been evaluated.

In this study, we examined the developmental change in the sensitivity of hypothalamic Kiss 1 and Kiss $1 \mathrm{r}$ mRNA expression to nutritional status in female rats. In addition, we have examined whether the acquisition of leptin sensitivity by the kisspeptin system is involved in the developmental changes in its sensitivity to nutritional status because the leptin sensitivity of other hypothalamic factors is established during the neonatal period.

\section{Materials and Methods}

\section{Animals}

Sprague-Dawley rats (Charles River Japan Inc., Tokyo, Japan) were used. The day the litters were born was considered as postnatal day 1 . The animals were housed in a room with controlled lighting (14 h light:10 h darkness cycle) and temperature $\left(24^{\circ} \mathrm{C}\right)$ and were weaned at postnatal day 21 . All animal experiments were conducted in accordance with the ethical standards of the Animal Care and Use Committee of the University of Tokushima.

\section{Effects of maternal and food deprivation on plasma hormone} concentrations and hypothalamic neuropeptide (GnRH, Kiss1, and Kiss1r) $m R N A$ levels at various developmental stages

To determine the effects of maternal deprivation (MD) and/or FD on hypothalamic neuropeptide mRNA levels at various developmental stages, female rats at postnatal days 5 , 15 , and 25 of age were divided into three groups: the control, the $12 \mathrm{~h} \mathrm{MD}$ or FD, and the $24 \mathrm{~h} \mathrm{MD}$ or FD groups $(n=7-8$ per group). The rats in all the groups were weighed, and the rats in the 12 and $24 \mathrm{~h}$ deprivation groups were separated from their mothers (postnatal day 5 or 15) or were deprived of food (postnatal day 25). At the end of the MD or FD, the animals were weighed and killed by decapitation between 0900 and $1000 \mathrm{~h}$ of the light cycle, and their blood and whole brain were collected. The rats in the control group were neither separated from their mothers nor deprived of food and were weighed again after $24 \mathrm{~h}$ and then killed by decapitation. The serum was separated by centrifugation and stored at $-20^{\circ} \mathrm{C}$, and the whole brain was snap frozen and stored at $-70{ }^{\circ} \mathrm{C}$. Before the RNA analysis, hypothalamic explants, including the median preoptic area, the anteroventral PeN (AVPV), and the ARC, were dissected out from the frozen brains according to the following methods, as described elsewhere (Castellano et al. 2006). A brain section was dissected out through an anterior coronal cut at $1 \mathrm{~mm}$ (postnatal days 5 and 10) or $2 \mathrm{~mm}$ (postnatal day 25) anterior from the optic chiasm and a posterior coronal cut at the posterior border of the mammillary bodies. Then, these tissue blocks were cut through two parasagittal cuts along the hypothalamic fissures and dorsally cut at $2.0 \mathrm{~mm}$ (postnatal days 5 and 10) or $2.5 \mathrm{~mm}$ (postnatal day 25) from the ventral surface.

The plasma leptin and LH (postnatal days 15 and 25) concentrations and the hypothalamic Kiss1, Kiss1r, and GnRH mRNA levels were then measured. As the sample volume for the postnatal day 5 rats was insufficient, the plasma LH concentration could not be measured. In the postnatal day 25 rats, the serum $E_{2}$ concentration, the ovarian weight, and the uterine weight were also measured because a change in the $\mathrm{E}_{2}$ concentration might have affected the hypothalamic Kiss 1 mRNA level.

\section{Effects of the co-administration of leptin on FD-induced alterations in plasma hormone concentrations and hypothalamic neuropeptide (Kiss1 and Kiss1r) mRNA levels}

To determine the effects of the co-administration of leptin on FD-induced alterations in plasma hormone concentrations and hypothalamic neuropeptide mRNA levels, the postnatal day 25 female rats were divided into three groups: the control, 
the $24 \mathrm{~h} \mathrm{FD}$, and the $24 \mathrm{~h}$ FD with leptin administration ( $24 \mathrm{~h} \mathrm{FD}+$ lep) groups $(n=7-8$ per group). The rats in the $24 \mathrm{~h} \mathrm{FD}+$ lep group were given i.p. injections of leptin ( $3 \mathrm{mg} / \mathrm{kg}$ body weight) at 12 and $21 \mathrm{~h}$ after the initiation of FD. This dose of leptin is sufficient to maintain the plasma leptin concentration above physiological levels for $13 \mathrm{~h}$ in neonatal rats (Proulx et al. 2002). We measured the plasma leptin concentration following exogenous leptin administration at the dose used in this study as a preliminary experiment. The rats in the control and $24 \mathrm{~h}$ FD groups were administered i.p. injections of saline at the same time points. At the end of the FD, the animals were killed by decapitation. The blood and whole brain were collected, and hypothalamic explants were dissected out as mentioned above. Then, plasma LH concentrations and hypothalamic GnRH, Kiss1, and Kiss $1 r$ mRNA levels were measured.

\section{Hormone assays}

The plasma leptin concentration was measured using an I-125 RIA kit (Rat leptin RIA kit, Linco Research Inc., St. Charles MO, USA). The sensitivity of the assay was $0.5 \mathrm{ng} / \mathrm{ml}$. The inter- and intra-assay coefficients of variation (CV) were $4 \cdot 8$ and $2 \cdot 4 \%$ respectively. The plasma $\mathrm{LH}$ concentration was measured using an I-125 RIA kit (Rat LH (I-125) RIA kit, Institute of Isotopes Co., Ltd, Tokyo, Japan). The sensitivity of the assay was $0.2 \mathrm{ng} / \mathrm{ml}$. The inter- and intra-assay CV values were 6.6 and $6.5 \%$ respectively. The plasma $E_{2}$ concentration was measured using an I-123 RIA kit (Double Antibody $\mathrm{E}_{2}$ kit, Diagnostic Products Co., Los Angeles, CA, USA). The sensitivity of the assay was $1.4 \mathrm{pg} / \mathrm{ml}$. The interand intra-assay CV values were $4 \cdot 1$ and $4 \cdot 6 \%$ respectively.

\section{Quantitative real-time PCR}

Total RNA was isolated from the hypothalamus using a TRIzol reagent kit (Invitrogen Co.) and an RNeasy Mini kit (Qiagen $\mathrm{GmbH}$ ). cDNA was synthesized with oligo (deoxythymidine) primers at $50{ }^{\circ} \mathrm{C}$ using the SuperScript III First-Strand Synthesis System for RT-PCR (Invitrogen Co.). Real-time PCR analysis was performed using the PCR System 7500 (PE Applied Biosystems, Foster City, CA, USA) with SYBR green. Sequence-specific primers were generated on the basis of the published rat sequences using the Primer3 software (Whitehead Institute/MIT Center for Genome Research; http://www.genome.wi.mit.edu). The forward and reverse primers used were as follows: Kiss 1 : F: $5^{\prime}$-AGC TGC TGC TGC TTC TCC TCT GT-3', R: 5'-AGG CTT GCT CTC TGC ATA CC- $3^{\prime}$; Kiss 1r: F: $5^{\prime}$-GCA GAC CGT CAC CAA TTT CT- $3^{\prime}$, R: $5^{\prime}$-GGG AAC ACA GTC ACG TAC CA-3'; GnRH: F: 5'-GCA GAA CCC CAG AAC TTG GA-3', R: $5^{\prime}$-TGC CCA GCT TCC TCT TCA AT-3'; and $\beta$-actin: F: $5^{\prime}$-TCA TGA AGT GTG ACG TTG ACA TCC GT-3', R: $5^{\prime}$-CTT AGA AGC ATT TGC GGT GCA CG- $3^{\prime}$. The PCR cycling conditions were as follows: initial denaturation and enzyme activation at $95^{\circ} \mathrm{C}$ for
$10 \mathrm{~min}$, followed by 45 cycles of denaturation at $95^{\circ} \mathrm{C}$ for $15 \mathrm{~s}$; annealing at $63{ }^{\circ} \mathrm{C}$ for $30 \mathrm{~s}$ (Kiss 1 , Kiss $1 r$ ), $58^{\circ} \mathrm{C}$ for $30 \mathrm{~s}$ $(\mathrm{G} n R H)$, or $65{ }^{\circ} \mathrm{C}$ for $30 \mathrm{~s}\left(\beta\right.$-actin); and extension at $72{ }^{\circ} \mathrm{C}$ for $1 \mathrm{~min}$. The copy numbers of the transcripts were normalized against those of $\beta$-actin transcripts for each sample.

\section{Statistical analysis}

Data were analyzed by one-way ANOVA followed by Fisher's protected least significant difference test. All results are presented as means \pm s.E.M. Differences were considered to be statistically significant at $P<0 \cdot 05$. Correlation analyses were performed using Spearman's correlation as appropriate.

\section{Results}

Effects of $M D$ and FD on the plasma leptin concentration and hypothalamic neuropeptide (GnRH, Kiss1, and Kiss1r) $m R N A$ levels at various developmental stages

In postnatal day 5 rats, body weight (one-way ANOVA; $P<0 \cdot 001, F(3,47)=22 \cdot 38)$ and plasma leptin concentration (one-way ANOVA; $P=0 \cdot 006, F(3,52)=6 \cdot 89)$ were significantly lower in the $12 \mathrm{~h} \mathrm{MD}$ and $24 \mathrm{~h} \mathrm{MD}$ groups than in the control group (Fig. 1). Similarly, the Kiss $1 r$ mRNA level was significantly lower in the $24 \mathrm{~h}$ MD group (one-way ANOVA; $P=0.002, F(3,49)=5 \cdot 01)$ than in the control group. However, the mRNA levels of GnRH (one-way ANOVA; $P=0 \cdot 306, F(3,47)=1 \cdot 26)$ and Kiss1 (one-way ANOVA; $P=0 \cdot 751, F(3,47)=0 \cdot 29)$ were not altered by MD.
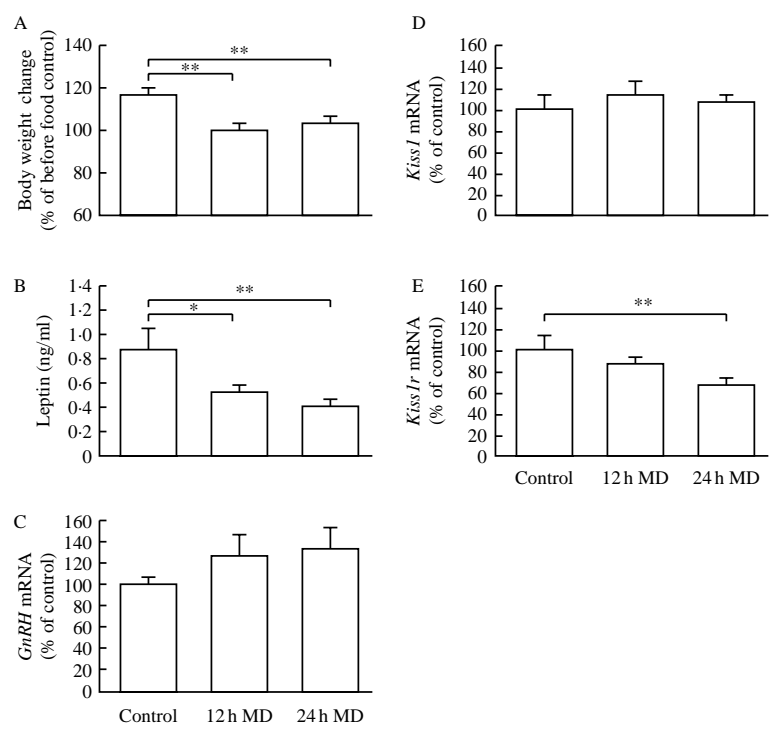

Figure 1 Effects of maternal food deprivation (MD) on body weight (A), plasma leptin concentration (B), and hypothalamic neuropeptide (GnRH, Kiss1, and Kiss1r) mRNA levels (C-E) in postnatal day 5 female rats. Values are expressed as the mean \pm S.E.M. ${ }^{*} P<0 \cdot 05,{ }^{* *} P<0 \cdot 01$. 
In the postnatal day 15 rats, body weight (one-way ANOVA; $P<0 \cdot 001, F(3,59)=102 \cdot 86)$ and the plasma leptin concentration (one-way ANOVA; $P<0 \cdot 001, F(3,63)=$ $34 \cdot 08$ ) were significantly lower in the $12 \mathrm{~h} \mathrm{MD}$ and $24 \mathrm{~h} \mathrm{MD}$ groups than in the control group (Fig. 2). However, the $G n R H$ (one-way ANOVA; $P=0 \cdot 310, F(3,59)=1 \cdot 25$ ), the Kiss 1 (one-way ANOVA; $P=0 \cdot 683, F(3,59)=0 \cdot 39)$, and the Kiss $1 r$ (one-way ANOVA; $P=0 \cdot 624, F(3,59)=0 \cdot 48$ ) mRNA levels were not altered by MD. Similarly, the plasma LH concentration was not altered by MD (one-way ANOVA; $P=0 \cdot 404, F(3,89)=0 \cdot 98)$.

In the postnatal day 25 rats, body weight (one-way ANOVA; $P<0 \cdot 001, F(3,47)=127 \cdot 30)$ and plasma leptin concentration (one-way ANOVA; $P<0.001, F(3,47)=$ $22 \cdot 95)$ were significantly lower in the $12 \mathrm{~h} \mathrm{FD}$ and $24 \mathrm{~h}$ FD groups than in the control group (Fig. 3). Similarly, the Kiss 1 (one-way ANOVA; $P=0 \cdot 040, F(3,47)=3 \cdot 73)$ and Kiss1r (one-way ANOVA; $P<0 \cdot 001, F(3,47)=13 \cdot 54)$ mRNA levels and the plasma LH concentration (one-way ANOVA; $P=0.008, F(3,49)=6.23)$ were significantly lower in the $24 \mathrm{~h} F D$ group than in the control group. However, the $G n R H$ (one-way ANOVA; $P=0 \cdot 446, F(3,47)=0 \cdot 84$ ) mRNA levels were not altered by FD. In addition, the serum $\mathrm{E}_{2}$ concentration (one-way ANOVA; $P=0 \cdot 249$, $F(3,52)=1 \cdot 50)$, the ovarian weight (one-way ANOVA; $P=0 \cdot 423, F(3,47)=0 \cdot 90)$, and the uterine weight (one-way ANOVA; $P=0.530, F(3,52)=0.66)$ were not altered, showing that $\mathrm{E}_{2}$ was not associated with changes in the Kiss 1 or Kiss $1 r$ mRNA level.

In the postnatal day 25 rats, the Kiss 1 mRNA expression level was not correlated with the plasma leptin
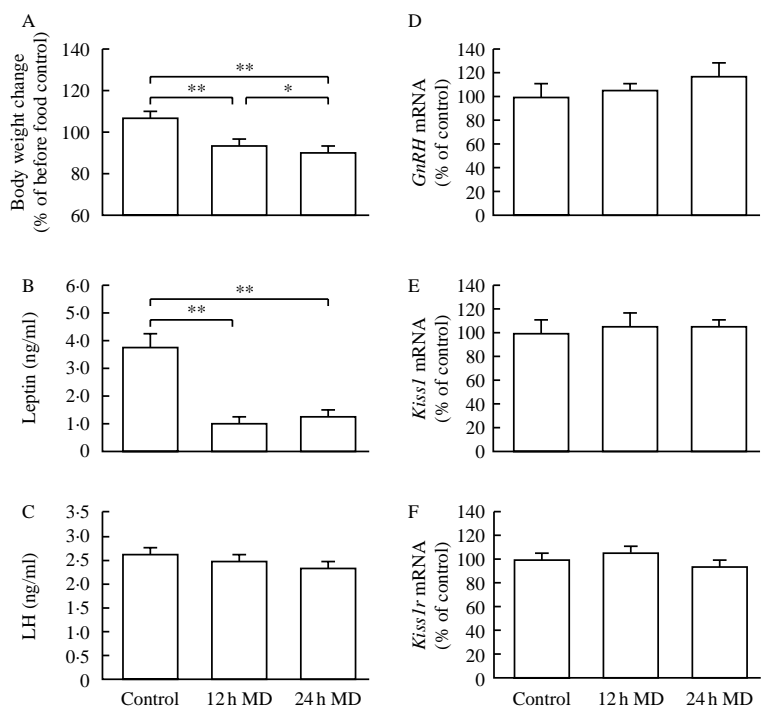

Figure 2 Effects of maternal food deprivation (MD) on body weight (A), plasma leptin concentration (B), plasma LH concentration (C), and hypothalamic neuropeptide (GnRH, Kiss1, and Kiss1r) mRNA levels (D-F) in postnatal day 15 female rats. Values are expressed as the mean \pm S.E.M. ${ }^{*} P<0 \cdot 05,{ }^{* *} P<0 \cdot 01$. concentration (Fig. 4). On the other hand, the Kiss1r mRNA expression level was positively correlated with the plasma leptin concentration.

Effects of leptin administration on FD-induced alterations in the plasma LH concentration and hypothalamic neuropeptide (Kiss1 and Kiss1r) $m R N A$ levels

In the postnatal day 25 rats, the plasma leptin concentration following exogenous leptin administration at the dose used in this study ( $3 \mathrm{mg} / \mathrm{kg}$ body weight) was significantly increased at each time point $(4 \cdot 5,9$, and $12 \mathrm{~h})$ compared with that of the saline-administered rats (Fig. 5). Co-administration of leptin restored the $24 \mathrm{~h}$ FD-induced reduction of Kiss $1 r$ mRNA expression (Kiss1r mRNA expression was significantly higher in the $24 \mathrm{~h}$ FD + lep group than in the $24 \mathrm{~h}$ FD group; Fig. 6). On the other hand, it did not restore the $24 \mathrm{~h}$ FD-induced reduction of Kiss 1 mRNA expression or the plasma LH concentration.

\section{Discussion}

In this study, we have shown that the sensitivity of the hypothalamic kisspeptin system to nutritional status in female rats changes during the developmental period. Hypothalamic Kiss 1 mRNA expression was reduced by FD at postnatal day 25 , but not in the early developmental period (postnatal days 5 and 15). These developmental changes in the sensitivity of Kiss 1 mRNA expression to nutritional status resemble their neuronal projection developmental patterns. It has been reported that no kisspeptin neurons were detected in the AVPV or PeN of female mice at postnatal day 15, after which they increased in number from postnatal day 25 until they had reached adult levels at the onset of puberty (Clarkson \& Herbison 2006). In addition, the close apposition between kisspeptin fibers and GnRH cell bodies becomes apparent at postnatal day 25 (Clarkson \& Herbison 2006). Thus, it is assumed that the sensitivity of the Kiss 1 mRNA expression to metabolic and nutritional status develops simultaneously with its neuronal projections during the neonatal period. These developmental patterns of the kisspeptin system resemble those of other endocrine and neuronal systems, i.e. the hypothalamus-pituitary-adrenal axis and the hypothalamic appetite regulatory system (Ahima et al. 1998, Mistry et al. 1999, Carlo et al. 2007). Many epidemiological and experimental studies have indicated that an abnormally high or low nutritional status or putative stress during the plastic period induces long-term alterations in physiological systems (Barker et al. 1993, Proulx et al. 2002, Yura et al. 2005, Bouret et al. 2008, Delahaye et al. 2008, Remmers et al. 2008, Breton et al. 2009, Kirk et al. 2009). Although these alterations are adaptations to environmental conditions, they often increase the risks of certain diseases in later life (Barker et al. 1993). Similarly, we have shown that prenatal undernutrition reduces hypothalamic Kiss 1 mRNA expression throughout 

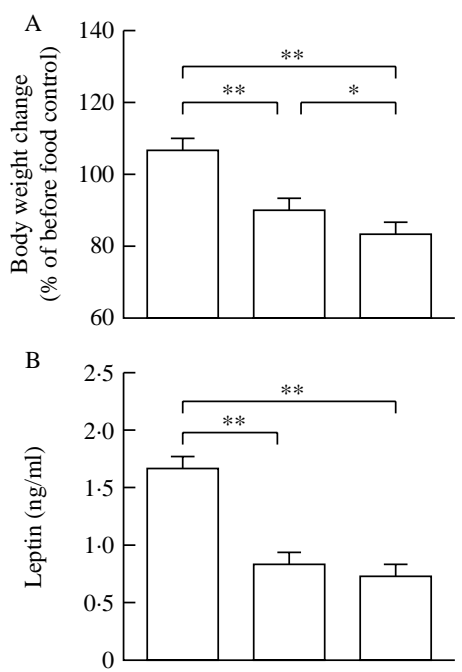

$\mathrm{C}$

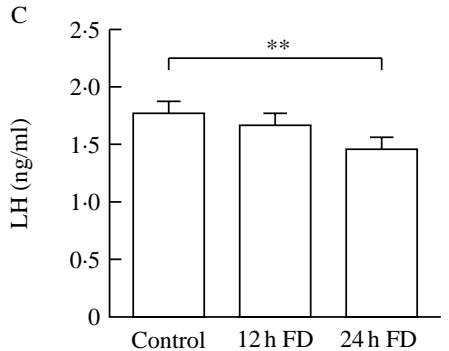

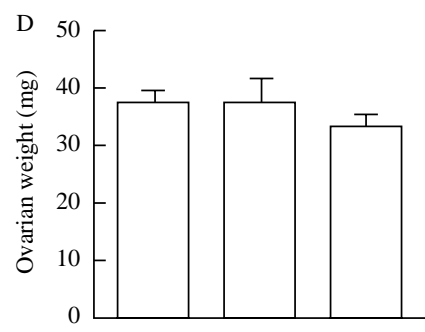
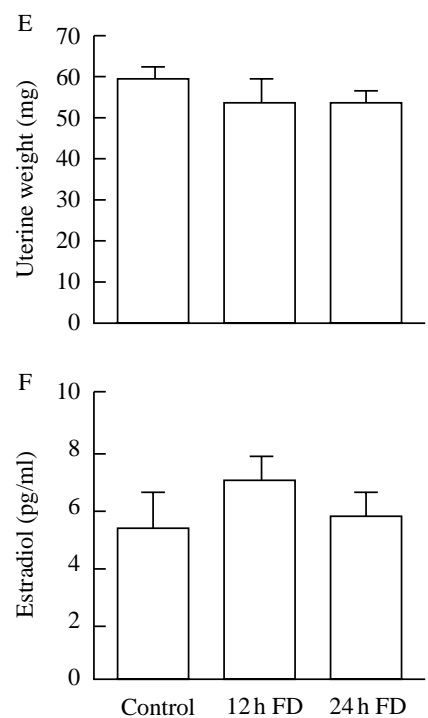
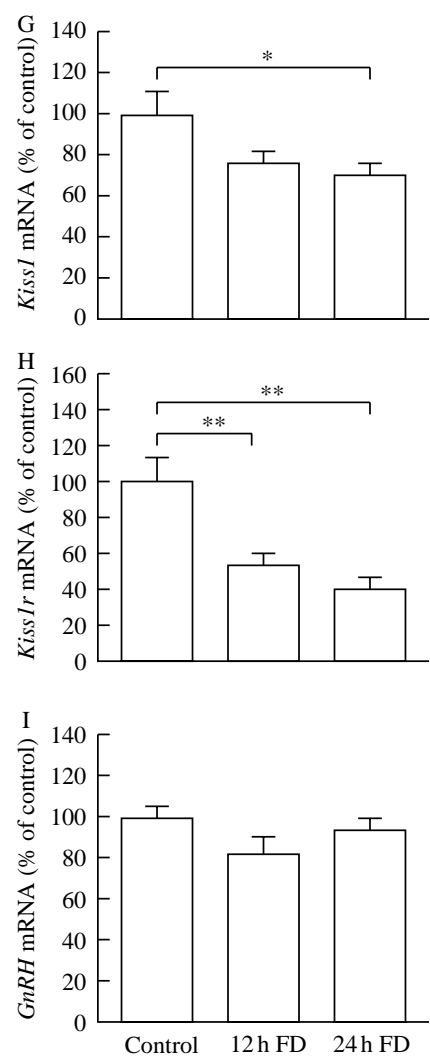

Figure 3 Effects of food deprivation (FD) on body weight (A), plasma leptin concentration (B), plasma LH concentration $(C)$, ovarian weight $(D)$, uterine weight $(E)$, plasma estradiol concentration $(F)$, and hypothalamic neuropeptide (GnRH, Kiss 1, and Kiss 1r) mRNA levels $(\mathrm{G}-\mathrm{l})$ in postnatal day 25 female rats. Values are expressed as the mean \pm s.E.M. ${ }^{*} P<0 \cdot 05,{ }^{* *} P<0 \cdot 01$.

the developmental period and that this alteration retards sexual maturation in female rats (Iwasa et al. 2010). Furthermore, another group demonstrated that neonatal immune stress reduces hypothalamic Kiss 1 mRNA levels during the prepubertal period in female rats (Knox et al. 2009). Therefore, it can be assumed that a negative energy balance in the early developmental period induces alterations in the hypothalamic kisspeptin system and negatively affects sexual maturation and reproductive function in later life. Further epidemiological and experimental studies are needed to clarify this hypothesis.

It has been reported that the sensitivities of some hypothalamic factors to leptin are established in the early developmental period. Therefore, we assumed that the acquisition of leptin sensitivity was involved in the establishment of the sensitivity of Kiss 1 mRNA expression to acute FD. However, contrary to our expectations, hypothalamic Kiss 1 mRNA expression was not correlated with the plasma leptin level, and the administration of leptin did not restore the reduced Kiss 1 mRNA and plasma LH levels induced by acute FD at postnatal day 25. As mentioned above, the plasma leptin concentration observed following exogenous leptin administration at the dose used in this study was significantly increased compared with that of the saline-administered rats. It is disputed whether hypoleptinemia plays a role in the suppression of reproductive hormones under acute foodrestricted conditions. For example, the suppression of plasma $\mathrm{LH}$ and testosterone levels in acute food-restricted male monkeys is not restored by short-term leptin administration (Lado-Abeal et al. 1999). Our present data also support the hypothesis that hypoleptinemia is not involved in the suppression of reproductive function induced by acute food restriction. As whole hypothalamic blocks containing both the AVPV and ARC were used for the gene expression analyses, the effects of FD and leptin on the Kiss 1 mRNA
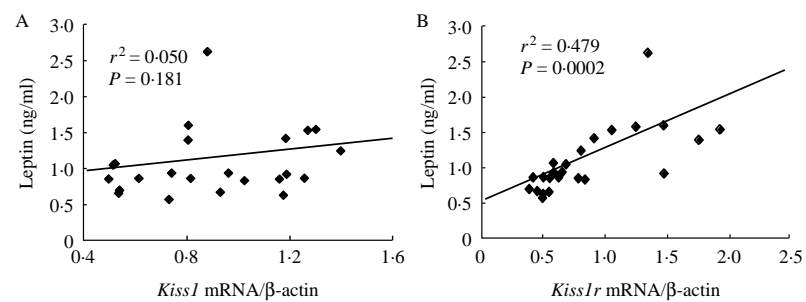

Figure 4 Correlations between the Kiss1 (A) or Kiss1r (B) mRNA level and the plasma leptin concentration in postnatal day 25 female rats. 


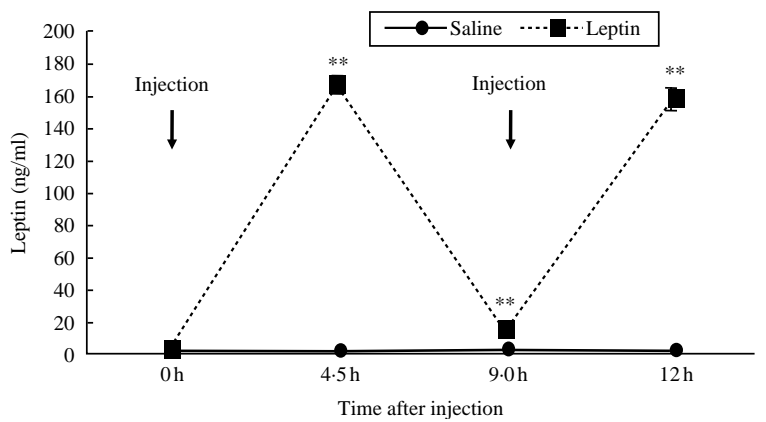

Figure 5 Time course of the changes in plasma leptin concentrations after saline or exogenous leptin ( $3 \mathrm{mg} / \mathrm{kg}$ body weight) administration in postnatal day 25 female rats. Values are expressed as the mean \pm S.E.M. ${ }^{* *} P<0 \cdot 01$ compared with the saline group.

expression in individual hypothalamic nuclei could not be examined. Therefore, it remains possible that subtle changes in gene expression in each nucleus might have escaped detection due to the use of whole hypothalamic blocks. In addition, it is possible that leptin regulates Kiss $1 \mathrm{mRNA}$ expression in an opposing manner in the AVPV and ARC, similar to estrogen, which stimulates Kiss 1 mRNA expression in the AVPV but inhibits it in the ARC (Oakley et al. 2009, Uenoyama et al. 2009). If this is true, the opposing regulatory effects of leptin might have canceled each other out, resulting in no change in the Kiss 1 mRNA expression level of the whole hypothalamic block. Further precise examinations, i.e. through in situ hybridization, are needed to clarify the effects of metabolic status and leptin on Kiss 1 mRNA expression in each nucleus.

We have shown that hypothalamic Kiss1r mRNA expression was reduced by acute FD at postnatal days 5 and 25 but not at day 15 . These findings suggest that the hypothalamic Kiss1r is sensitive to metabolic status from the early neonatal period onward. These developmental changes in the sensitivity of Kiss $1 \mathrm{r}$ mRNA expression to metabolic status were different from those of Kiss1 mRNA expression. As Kiss $1 \mathrm{mRNA}$ is expressed in kisspeptin neurons, it is reasonable that the developmental changes observed in the sensitivity of Kiss 1 mRNA expression to metabolic status fit well with the pattern of kisspeptin neuron development during the neonatal period. On the contrary, Kiss $1 r$ mRNA is expressed in another neuronal population, i.e. GnRH neurons in the preoptic area. Thus, the developmental changes observed in the sensitivity of Kiss $1 r$ mRNA expression to metabolic status do not fit with the developmental pattern of kisspeptin neurons.

We have also shown that the hypothalamic Kiss $1 r$ mRNA level was correlated with the plasma leptin level and that the administration of leptin restored the reduced Kiss $1 r$ mRNA expression level induced by acute FD at postnatal day 25, suggesting that hypoleptinemia plays a role in the reduction of Kiss $1 r$ mRNA expression induced by acute FD. On the other hand, the administration of a dose of leptin above the physiological range in normal fed rats did not increase the hypothalamic Kiss1r mRNA levels in our preliminary evaluation $(1.50 \pm 0.19$ (control) versus $1 \cdot 24 \pm 0 \cdot 13$ (leptin administration), mean \pm s.E.M). Therefore, it is assumed that Kiss $1 r$ mRNA expression remains stable when the serum leptin levels are within or above the normal range and that its expression decreases when the plasma leptin level falls below the lower threshold of the normal range. In rodents, the plasma leptin level increases around postnatal days 8-16, which is called the leptin surge (Yura et al. 2005). In this study, the plasma leptin level of the control group at postnatal day $15(4 \cdot 04 \pm 0 \cdot 45 \mathrm{ng} / \mathrm{ml}$, mean \pm s.E.M. $)$ was significantly higher than that at day $5(0.88 \pm 0.14 \mathrm{ng} / \mathrm{ml})$ and day 25 $(1 \cdot 62 \pm 0 \cdot 15 \mathrm{ng} / \mathrm{ml})$. In addition, the plasma leptin level of the $24 \mathrm{~h}$ FD group at postnatal day $15(1.31 \pm 0 \cdot 13 \mathrm{ng} / \mathrm{ml}$, mean \pm s.E.M.) was also significantly higher than that at day 5 $(0.40 \pm 0.05 \mathrm{ng} / \mathrm{ml})$ and day $25(0.78 \pm 0.06 \mathrm{ng} / \mathrm{ml})$. We suppose that the plasma leptin level had not fallen below the level required to maintain the hypothalamic Kiss $1 r$ mRNA level by postnatal day 15, even after FD. If the MD had been continued for longer than $24 \mathrm{~h}$ in the postnatal day 15 rats, we assume that the plasma leptin level would have fallen below the lower threshold of the normal range, causing hypothalamic Kiss1r mRNA expression to decrease. We also speculate that the lower threshold of the plasma leptin level required to maintain Kiss1r mRNA expression is raised during development and that higher plasma leptin levels are required to maintain Kiss $1 r$ mRNA expression in postnatal day 25 rats compared with postnatal day 15 rats. However, it is unclear whether alterations in hypothalamic Kiss $1 r$ mRNA expression at postnatal day 5 or 25 play a role in fastinginduced suppression of reproductive function because the restoration of the Kiss $1 r$ mRNA level by leptin administration did not affect the plasma LH level in this study. Further examinations are needed to clarify the physiological roles of these alterations.
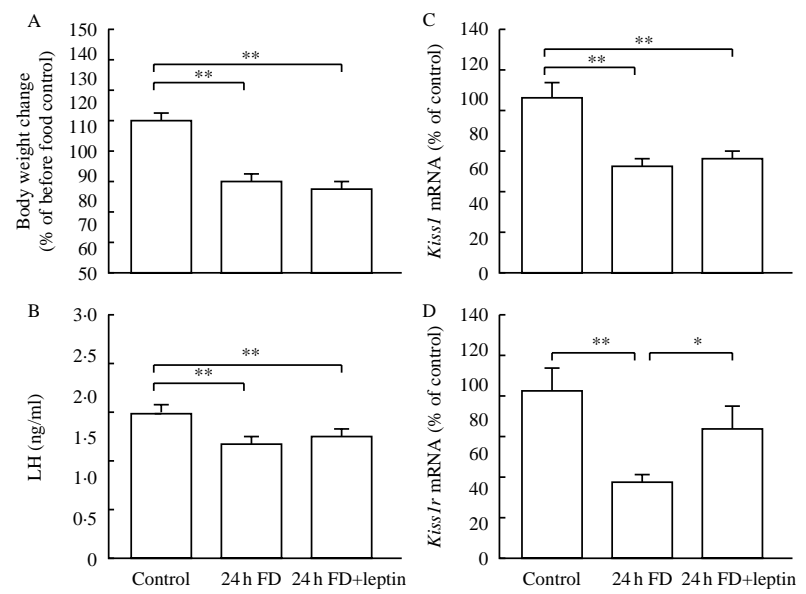

Figure 6 Effects of leptin administration on $24 \mathrm{~h}$ food deprivation (FD)-induced alterations in body weight (A), plasma LH concentration (B), and neuropeptide (Kiss1 and Kiss1r) mRNA levels $(\mathrm{C}$ and $\mathrm{D})$ in postnatal day 25 female rats. Values are expressed as the mean \pm S.E.M. $* P<0 \cdot 05, * * P<0 \cdot 01$. 
In this study, we have focused on the acute changes that occur following MD or FD and leptin administration. However, leptin is regarded as a key signal for the longterm control of energy balance. It has been reported that the chronic negative energy balance caused by diabetes mellitus reduces Kiss 1 mRNA expression and that chronic leptin infusion is sufficient to normalize the Kiss $1 \mathrm{mRNA}$ level (Castellano et al. 2006). Thus, it remains possible that longer treatment with leptin can rescue Kiss 1 mRNA expression under chronic food restriction.

In summary, we have shown that the sensitivity of the hypothalamic mRNA expression of Kiss1 and Kiss $1 r$ mRNA to nutritional status is altered during the development in female rats. The sensitivity of hypothalamic Kiss 1 mRNA expression to acute FD was not established during the early neonatal period; however, it had become apparent by postnatal day 25. It is speculated that these alterations in the sensitivity of kisspeptin neurons to nutritional status develop simultaneously with their neuronal projections during the neonatal period. On the other hand, the sensitivity of hypothalamic Kiss $1 r$ mRNA expression to acute FD may be established in the early neonatal period. In addition, the reduced Kiss $1 r$ mRNA expression observed in undernourished conditions may be caused by decreases in serum leptin levels.

\section{Declaration of interest}

The authors declare that there is no conflict of interest that could be perceived as prejudicing the impartiality of the research reported.

\section{Funding}

This research did not receive any specific grant from any funding agency in the public, commercial or not-for-profit sector.

\section{References}

Ahima RS, Prabakaran D \& Flier JS 1998 Postnatal leptin surge and regulation of circadian rhythm of leptin by feeding. Journal of Clinical Investigation 101 1020-1027. (doi:10.1172/JCI1176)

Barker DJ, Gluckman PD, Godfrey KM, Harding JE, Owens JA \& Robinson JS 1993 Fetal nutrition and cardiovascular disease in adult life. Lancet 341 938-941. (doi:10.1016/0140-6736(93)91224-A)

Bouret SG 2010 Review: neurodevelopmental action of leptin. Brain Research 1350 2-9. (doi:10.1016/j.brainres.2010.04.011)

Bouret SG, Draper SJ \& Simerly RB 2004 Trophic action of leptin on hypothalamic neurons that regulate feeding. Science 304 108-110. (doi:10.1126/science.1095004)

Bouret SG, Gorski JN, Paterson CM, Chen S, Levin BE \& Simerly RB 2008 Hypothalamic neural projections are permanently disrupted in dietinduced obese rats. Cell Metabolism 7 179-185. (doi:10.1016/j.cmet.2007. 12.001)

Breton C, Lukaszewski MA, Risold PY, Enache M, Guillemot J, Riviere G, Delahaye F, Lesage J, Dutriez-Casteloot I, Laborie C et al. 2009

Maternal prenatal undernutrition alters the response of POMC neurons to energy status variation in adult male rat offspring. American Journal of Physiology. Endocrinology and Metabolism 296 E462-E472. (doi:10.1152/ ajpendo.90740.2008)

Brown RE, Imran SE, Ur E \& Wilkinson M 2008 KiSS-1 mRNA in adipose tissue is regulated by sex hormones and food intake. Molecular and Cellular Endocrinology 281 64-72. (doi:10.1016/j.mce.2007.10.011)

Cagampang FR, Maeda KI, Tsukamura H, Ohkura S \& Ota K 1991 Involvement of ovarian steroids and endogenous opioids in the fasting-induced suppression of pulsatile LH release in ovariectomized rats. Journal of Endocrinology 129 321-328. (doi:10.1677/joe.0.1290321)

Carlo AS, Pyrski M, Loudes C, Faivre-Baumann A, Epelbaum J, Williams LM \& Meyerhof W 2007 Leptin sensitivity in the developing rat hypothalamus. Endocrinology 148 6073-6082. (doi:10.1210/en.2007-0822)

Castellano JM, Navarro VM, Fernandez-Fernandez R, Nogueiras R, Tovar S, Roa J, Vazquez MJ, Vigo E, Casanueva FF, Aguilar E et al. 2005 Changes in hypothalamic KiSS-1 system and restoration of pubertal activation of the reproductive axis by kisspeptin in undernutrition. Endocrinology 146 3917-3925. (doi:10.1210/en.2005-0337)

Castellano JM, Navarro VM, Fernandez-Fernandez R, Roa J, Vigo E, Pineda R, Dieguez C, Aguilar E, Pinilla L \& Tena-Sempere M 2006 Expression of hypothalamic KiSS-1 system and rescue of defective gonadotropic responses by kisspeptin in streptozotocin-induced diabetic male rats. Diabetes 55 2602-2610. (doi:10.2337/db05-1584)

Castellano JM, Roa J, Luque RM, Dieguez C, Aguilar E, Pinilla L \& Tena-Sempere M 2009 Review: KiSS-1/kisspeptins and the metabolic control of reproduction: physiologic roles and putative physiopathological implications. Peptides 30 139-145. (doi:10.1016/j.peptides.2008.06.007)

Clarkson J \& Herbison AE 2006 Postnatal development of kisspeptin neurons in mouse hypothalamus; sexual dimorphism and projections to gonadotropin-releasing hormone neurons. Endocrinology 147 5817-5825. (doi:10.1210/en.2006-0787)

Delahaye F, Breton C, Risold PY, Enache M, Dutriez-Casteloot I, Laborie C, Lesage J \& Vieau D 2008 Maternal perinatal undernutrition drastically reduces postnatal leptin surge and affects the development of arcuate nucleus proopiomelanocortin neurons in neonatal male rat pups. Endocrinology 149 470-475. (doi:10.1210/en.2007-1263)

Gottsch ML, Cunningham MJ, Smith JT, Popa SM, Acohido BV, Crowley WF, Seminara S, Clifton DK \& Steiner RA 2004 A role for kisspeptins in the regulation of gonadotropin secretion in the mouse. Endocrinology 145 4073-4077. (doi:10.1210/en.2004-0431)

Irwig MS, Fraley GS, Smith JT, Acohido BV, Popa SM, Cunningham MJ, Gottsch ML, Clifton DK \& Steiner RA 2004 Kisspeptin activation of gonadotropin releasing hormone neurons and regulation of KiSS-1 mRNA in the male rat. Neuroendocrinology 80 264-272. (doi:10.1159/000083140)

Iwasa T, Matsuzaki T, Murakami M, Fujisawa S, Kinouchi R, Gereltsetseg G, Kuwahara A, Yasui T \& Irahara M 2010 Effects of intrauterine undernutrition on hypothalamic Kiss1 expression and the timing of puberty in female rats. Journal of Physiology $\mathbf{5 8 8}$ 821-829. (doi:10.1113/jphysiol.2009.183558)

Kirk SL, Samuelsson AM, Argenton M, Dhonye H, Kalamatianos T, Poston L, Taylor PD \& Coen CW 2009 Maternal obesity induced by diet in rats permanently influences central processes regulating food intake in offspring. PLOS ONE 4 e5870. (doi:10.1371/journal.pone.0005870)

Knox AM, Li XF, Kinsey-Jones JS, Wilkinson ES, Wu XQ, Cheng YS, Milligan SR, Lightman SL \& O’Byrne KT 2009 Neonatal lipopolysaccharide exposure delays puberty and alters hypothalamic Kiss1 and Kiss1r mRNA expression in the female rat. Journal of Neuroendocrinology 21 683-689. (doi:10.1111/j.1365-2826.2009.01885.x)

Knuth UA \& Friesen HG 1983 Starvation induced anoestrus: effect of chronic food restriction on body weight, its influence on oestrous cycle and gonadotrophin secretion in rats. Acta Endocrinologica 104 402-409. (doi:10. 1530/acta.0.1040402)

Kohsaka A, Watanobe H, Kakizaki Y, Suda T \& Schioth HB 2001 A significant participation of orexin-A, a potent orexigenic peptide, in the preovulatory luteinizing hormone and prolactin surge in the rat. Brain Research 898 166-170. (doi:10.1016/S0006-8993(01)02157-6)

Lado-Abeal J, Lukyanenko YO, Swamy S, Hermida RC, Hutson JC \& Norman RL 1999 Short-term leptin infusion does not affect circulating 
levels of $\mathrm{LH}$, testosterone or cortisol in food-restricted pubertal male rhesus macaques. Clinical Endocrinology 51 41-51. (doi:10.1046/j.1365-2265. 1999.00727.x)

Luque RM, Kineman RD \& Tena-Sempere M 2007 Regulation of hypothalamic expression of KiSS-1 and GPR 54 genes by metabolic factors: analyses using mouse models and a cell line. Endocrinology 148 4601-4611. (doi:10.1210/en.2007-0500)

McClure TJ \& Saunders J 1985 Effects of withholding food for $0-72 \mathrm{~h}$ on mating, pregnancy rate and pituitary function in female rats. Journal of Reproduction and Fertility 74 57-64. (doi:10.1530/jrf.0.0740057)

Messager S, Chatzidaki EE, Ma D, Hendrick AG, Zahn D, Dixon J, Thresher RR, Malinge I, Lomet D, Carlton MB et al. 2005 Kisspeptin directly stimulates gonadotropin-releasing hormone release via $\mathrm{G}$ protein-coupled receptor 54. PNAS 102 1761-1766. (doi:10.1073/pnas. 0409330102)

Mistry AM, Swick A \& Romsos DR 1999 Leptin alters metabolic rates before acquisition of its anorectic effect in developing neonatal mice. American Journal of Physiology 277 742-747.

Morelli A, Marini M, Mancina R, Luconi M, Vignozzi L, Fibbi B, Filippo S, Pezzatini A, Forti G, Vannelli GB et al. 2008 Sex steroids and leptin regulate the "first kiss" (KiSS1/G-protein-coupled receptor 54 system) in human gonadotropin-releasing-hormone-secreting neuroblasts. Journal of Sexual Medicine 5 1097-1113. (doi:10.1111/j.1743-6109.2008.00782.x)

Navarro VM, Fernandez-Fernandez R, Castellano JM, Roa J, Mayen A, Barreiro ML, Gaytan F, Aguilar E, Pinilla L, Dieguez C et al. 2004 Advanced vaginal opening and precocious activation of the reproductive axis by KiSS-1 peptide, the endogenous ligand of GPR 54. Journal of Physiology 561 379-386. (doi:10.1113/jphysiol.2004.072298)

Navarro VM, Castellano JM, Fernandez-Fernandez R, Tovar S, Roa J, Mayen A, Nogueiras R, Vazquez MJ, Barreiro ML, Magni P et al. 2005 Characterization of the potent luteinizing hormone releasing activity of KiSS-1 peptide, the natural ligand of GPR54. Endocrinology 146 156-163. (doi:10.1210/en.2004-0836)

Oakley AE, Clifton DK \& Steiner RA 2009 Review. Kisspeptin signaling in the brain. Endocrine Reviews 30 713-743. (doi:10.1210/er.2009-0005)

Proulx K, Richard D \& Walker CD 2002 Leptin regulates appetite-related neuropeptides in the hypothalamus of developing rats without affecting food intake. Endocrinology 143 4683-4692. (doi:10.1210/en.2002-220593)

Remmers F, Verhagen LA, Adan RA \& Delemarre-van de Waal HA 2008 Hypothalamic neuropeptide expression of juvenile and middle-aged rats after early postnatal food restriction. Endocrinology 149 3617-3625. (doi:10. 1210/en.2007-1388)
Roa J, Garcia-Galiano D, Castellano JM, Gaytan F, Pinilla L \& Tena-Sempere M 2010 Review. Metabolic control of puberty onset: new players, new mechanisms. Molecular and Cellular Endocrinology 324 87-94. (doi:10.1016/ j.mce.2009.12.018)

Roseweir AK \& Millar RP 2009 Review: the role of kisspeptin in the control of gonadotrophin secretion. Human Reproduction Update 15 203-212. (doi:10.1093/humupd/dmn058)

de Roux N, Genin E, Carel JC, Matsuda F, Chaussain JL \& Milgrom E 2003 Hypogonadotropic hypogonadism due to loss of function of the KiSS-1derived peptide receptor GPR54. PNAS 100 10972-10976. (doi:10.1073/ pnas.1834399100)

Seminara SB, Messager S, Chatzidaki EE, Thresher RR, Acierno JS Jr, Shagoury JK, Bo-Abbas Y, Kuohung W, Schwinof KM, Hendrick AG et al. 2003 The GPR 54 gene as a regulator of puberty. New England Journal of Medicine 349 1614-1627. (doi:10.1056/NEJMoa035322)

Shahab M, Mastronardi C, Seminara SB, Crowley WF, Ojeda SR \& Plant TM 2005 Increased hypothalamic GPR54 signaling: a potential mechanism for initiation of puberty in primates. PNAS 102 2129-2134. (doi:10.1073/ pnas.0409822102)

Smith JT, Acohido BV, Clifton DK \& Steiner RA 2006 KiSS-1 neurones are direct targets for leptin in the ob/ob mouse. Journal of Neuroendocrinology 18 298-303. (doi:10.1111/j.1365-2826.2006.01417.x)

Uenoyama Y, Tsukamura H \& Maeda KI 2009 Review. Kisspeptin/metastin: a key molecule controlling two modes of gonadotrophin-releasing hormone/luteinizing hormone release in female rats. Journal of Neuroendocrinology 21 299-304. (doi:10.1111/j.1365-2826.2009.01853.x)

Wade GN \& Schneider JE 1992 Review: metabolic fuels and reproduction in female mammals. Neuroscience and Biobehavioral Reviews 16 235-272. (doi:10.1016/S0149-7634(05)80183-6)

Yura S, Itoh H, Sagawa N, Yamamoto H, Masuzaki H, Nakao K, Kawamura M, Takemura M, Kakui K, Ogawa Y et al. 2005 Role of premature leptin surge in obesity resulting from intrauterine undernutrition. Cell Metabolism 1 371-378. (doi:10.1016/j.cmet.2005.05.005)

\section{Received in final form 11 August 2010 \\ Accepted 31 August 2010 \\ Made available online as an Accepted Preprint 31 August 2010}

